\title{
Makna susu bagi konsumen mahasiswa di kafe susu di Yogyakarta: antara gizi dan gengsi
}

Meaning of milk for students consumer at milk cafe in Yogyakarta: between nutrition and prestige

\author{
Atik Triratnawati \\ Departemen Antropologi, Fakultas Ilmu Budaya Universitas Gadjah Mada
}

\begin{abstract}
Background: The rise of milk cafe in Yogyakarta with visitors of student raises a question mark what purpose they consume milk. There is definitely an attraction that encourages students are willing to spend time, effort, and expenses for the sake of enjoying a glass of milk that can actually be done at home. Objective: To find the meaning of intrinsic and extrinsic of students consumer milk cafe in Yogyakarta. Method: This was a qualitative study using observation and in-depth interview with student consumer at milk cafe in DIY. Results: A new lifestyle among students appearing through hanging out in cafes milk for the purpose of the task, sharing, refreshing. Visitors cafes in addition to experience the benefits of drinking milk fresh milk with a variety of flavors, so the fishy taste is lost and replaced various delicious new taste sensation. They are also regarded as a milk cafe hangout for young slang. Place milk cozy cafe, with music, attractive interior, wifi facility on site to make it become a means for a selfie and comfortable group meetings. Conclusion: Nutrition of milk was not important things for them. Prestige then attached to the visitor's cafe milk given modern attributes and symbols attached to their lifestyle. The symbolic meaning of milk consumption in cafe milk is stronger than the natural sign, so the students are still high in demand for cafe milk.
\end{abstract}

KEYWORDS: cafe milk; nutrition; prestige; students; Yogyakarta

\begin{abstract}
ABSTRAK
Latar belakang: Maraknya kafe susu di Yogyakarta dengan pengunjung mahasiswa memunculkan tanda tanya apa tujuan mereka mengkonsumsi susu. Pasti ada daya tarik yang mendorong mahasiswa bersedia mengeluarkan waktu, tenaga, biaya, demi menikmati segelas susu yang sebenarnya bisa dilakukan di rumah. Tujuan: Mencari makna intrinsik dan ekstrinsik dari konsumen mahasiswa di kafe susu di Yogyakarta. Metode: Penelitian kualitatif dengan obserbvasi dan wawancara mendalam pada konsumen mahasiswa di kafe susu DIY. Hasil: Gaya hidup baru di kalangan mahasiswa muncul lewat nongkrong di kafe susu untuk tujuan mengerjakan tugas, sharing, dan refreshing. Pengunjung kafe susu merasakan manfaat minum susu segar dengan aneka variasi rasa sehingga rasa amis susu hilang diganti berbagai sensasi rasa baru yang enak. Mereka juga menganggap kafe susu sebagai tempat nongkrong yang gaul bagi anak muda. Tempat kafe susu yang nyaman, dengan musik, interior yang menarik, fasilitas wifi menjadikan lokasi itu menjadi ajang untuk selfie serta pertemuan kelompok yang nyaman. Simpulan: Nilai gizi susu tidak menjadi perhatian bagi konsumen mahasiswa. Gengsi melekat pada mahasiswa pengunjung kafe susu mengingat atribut modern serta simbol-simbol yang melekat pada gaya hidup mereka. Makna simbolik konsumsi susu di kafe susu lebih kuat daripada makna ekstrinsik sehingga animo remaja ke kafe susu tetap tinggi.
\end{abstract}

KATA KUNCI: kafe susu; gizi; gengsi; mahasiswa; Yogyakarta

\section{PENDAHULUAN}

Semenjak hari minum susu atau milk day sedunia yang jatuh setiap tanggal 1 Juni diperingati negara-negara di dunia, semakin menegaskan pentingnya minum susu dalam kehidupan manusia. Promosi susu baik di sekolah maupun di masyarakat semakin gencar (1). Minuman susu lekat dengan label sebagai minuman kesehatan, kebugaran dan penuh gizi. Oleh karena itu, semua orang dalam setiap kelompok usia akan membiasakan minum susu jika ingin sehat.

Namun, dalam praktik kehidupan sehari-hari masyarakat Indonesia, susu masih dianggap minuman

Korespondensi: Atik Triratnawati, Departemen Antropologi, Fakultas Ilmu Budaya Universitas Gadjah Mada Jl. Sosio Humaniora No. 1, Bulaksumur, Sleman, Yogyakarta 55281, Indonesia, e-mail: atik-tri@ugm.ac.id 
yang asing kecuali dicampur bahan lain seperti kopi. Susu belum merupakan budaya konsumsi sehari-hari masyarakat. Kondisi ini ironis dengan wilayah peternakan sapi di Indonesia yang cukup besar, ditambah adanya sapi impor, tetapi konsumsi susu oleh masyarakat umum masih tetap rendah. Salah satu penyebabnya karena harga susu yang belum terjangkau oleh daya beli masyarakat (2). Rendahnya tingkat konsumsi susu penduduk Indonesia dapat dibandingkan dengan negara tetangga. Tahun 2013 konsumsi susu di Indonesia mencapai 11,90 liter dari target 20 liter per kapita per tahun. Sementara itu, konsumsi di Singapura mencapai 30 liter/kapita/ tahun; Malaysia 22,10 liter/kapita/tahun; Thailand 33,7 liter/kapita/tahun; dan India 42,08 liter/kapita/tahun (3). Susu selain mahal harganya bagi masyarakat Indonesia, juga bukan menjadi prioritas utama untuk dikonsumsi. Ditambah lagi susu hanya dianggap sebagai penyempurna makanan sehingga hal tersebut bukan dianggap faktor penting dalam suatu menu makanan.

Banyak kendala yang masih ditemukan dalam mempopulerkan susu sebagai minuman sehat. Pada umumnya, dalam makanan sehari-hari orang Indonesia belum memenuhi gizi seimbang. Gizi seimbang diartikan sebagai ragam bahan makanan yang berkualitas, jumlah dan proporsi yang sesuai sehingga dapat memenuhi kebutuhan gizi seseorang guna pertumbuhan dan perkembangan yang optimal. Beberapa alasan tidak terpenuhinya gizi seimbang adalah banyak masyarakat miskin di Indonesia yang berprinsip makan asal kenyang yaitu mengkonsumsi makanan yang murah walaupun kurang bergizi. Susu yang menjadi salah satu komponen makanan seimbang dan sempurna dianggap sebagai minuman yang amis sehingga kurang disukai banyak orang. Terlebih lagi bagi gadis remaja yang menganggap bahwa mengkonsumsi susu menyebabkan kegemukan sehingga akan mengurangi daya tarik lawan jenisnya (4). Kondisi ini didukung oleh angka prevalensi obesitas pada laki-laki di Daerah Istimewa Yogyakarta (DIY) sebesar 8,3\% lebih rendah dibandingkan perempuan yang mencapai 15,7\% (5).

Seiring persoalan minimnya konsumsi susu pada masyarakat Indonesia, kebiasaan minum susu terus dipromosikan oleh tenaga kesehatan dan para produsen susu. Jumlah remaja yang cukup besar di
Indonesia telah menjadi sasaran para produsen susu. Remaja sangat tertarik dengan hal-hal yang baru. Kondisi tersebut dimanfaatkan oleh pengusaha makanan untuk mempromosikan produk mereka dengan cara yang sangat mempengaruhi perilaku remaja dalam hal mengkonsumsi suatu makanan atau minuman. Salah satu produk baru yang membidik konsumen remaja khususnya mahasiswa adalah munculnya produk varian susu rasa yang dijual di kafe susu. Mahasiswa dianggap sebagai kelompok yang membutuhkan mineral pembentuk tulang seperti kalsium yang kebutuhannya meningkat sejalan dengan berlangsungnya proses pertumbuhan tulang (6). Kalsium merupakan mineral paling banyak dalam tubuh. Sebanyak $99 \%$ kalsium terdapat dalam tulang dan gigi serta sisanya $1 \%$ terdapat dalam darah dan jaringan lunak (7). Mahasiswa juga merupakan kelompok yang paling mudah berubah gaya hidupnya sehingga semua hal-hal yang baru akan dicobanya. Gaya hidup mereka pula yang kemudian akan menjadi acuan teman sebaya (peer groups) untuk menirunya sehingga pangsa pasar kelompok ini tidak akan ada habisnya untuk dieksploitasi para pengusaha.

Media berperan dalam mengkonstruksi bagaimana menjadi kaum muda yang gaul dan trendi yang semuanya direpresentasikan lewat produk yang ditawarkan industri. Style atau gaya dimunculkan lewat berbagai produk, bisa berupa pakaian, hobi, makanan-minuman, musik, dan lainnya. Style dalam hal ini menjadi faktor penting dalam mendefinisikan diri karena style adalah suatu jalan untuk menghadirkan diri dan jalan untuk menilai orang lain (8). Akibatnya, kaum muda kota akan selalu mengejar apa yang menjadi gaya hidup di lingkungannya agar mereka dapat mengidentikkan diri sebagai bagian kaum muda masa kini.

Beberapa tahun terakhir, bermunculan kafe susu di DIY yang menghidangkan susu murni atau segar dengan beragam rasa dan tampilan sehingga sangat menarik minat pembeli khususnya kaum muda. Susu segar adalah hasil pemerasan sapi secara langsung, tanpa ditambah zat-zat lain ataupun mengalami pengolahan. Susu segar tidak memiliki rasa manis tetapi justru mengandung protein 3 kali konsentrasinya dibandingkan dengan susu kental manis (2). Susu juga sarat dengan kandungan vitamin A, B2, protein, potasium, dan berbagai asam 
amino. Susu mengandung vitamin yang dapat larut dalam lemak termasuk vitamin A, D, E, dan K (9). Disebutkan bahwa bahan susu dan produk susu yang mengandung vitamin D dan kalsium dapat mencegah terjadinya DM tipe 2. Kombinasi konsumsi vitamin D dan kalsium memberi risiko paling rendah terhadap terjadinya DM (10). Manfaat susu tidak hanya untuk memperkuat serta pertumbuhan tulang, mencegah osteoporosis, ketajaman penglihatan, ketahanan jantung dan saraf dari kelelahan, penyembuhan luka, tetapi juga membantu terlelap saat tidur malam (11).

Kafe yang biasanya identik dengan kopi, teh, sekarang justru yang paling banyak peminatnya adalah kafe susu. Pengunjung kafe susu di Yogyakarta ini didominasi kaum muda khususnya mahasiswa atau pelajar. Apabila di kaki lima bisa ditemukan minuman susu Boyolali yang terkenal, yang hanya bisa dinikmati dengan rasa coklat atau tanpa rasa serta dihidangkan panas maka yang khas dari kafe susu adalah susu dapat dinikmati dingin karena disimpan dalam almari pendingin. Kondisi ini menjadi fenomena yang menarik mengingat di satu sisi susu kurang disukai banyak orang, sebaliknya kafe susu justru digandrungi kaum remaja.

Usia remaja merupakan masa yang penting dalam kelangsungan hidup manusia. Masa ini merupakan masa transisi dari masa anak-anak ke masa dewasa yang ditandai dengan pertumbuhan dan perkembangan yang cepat baik fisik maupun mental, aktivitas yang makin meningkat serta sering disertai dengan perubahan pola konsumsi pangan (12). Susu merupakan komponen penting dalam pertumbuhan anak maupun orang dewasa. Susu kaya akan kandungan vitamin dan mineral. Vitamin tersebut berguna untuk pengembangan tulang dan kulit. Apabila tubuh manusia kekurangan vitamin-vitamin yang terkandung di dalam susu maka akan berakibat pada penyakit xeroptalmia serta kerusakan otak dan kulit (13).

Meski susu telah jelas kandungan gizinya, tetapi susu juga memiliki mitos. Mitos susu meliputi susu sapi diciptakan khusus untuk anak sapi; susu tidak baik bagi kesehatan manusia dan buruk bagi tulang; susu meningkatkan angka kematian dan risiko retak tulang; susu yang diproses lebih berbahaya daripada susu segar; susu menyebabkan obesitas pada remaja dan anak; minum susu dapat mengakibatkan batu ginjal dan menimbulkan jerawat, dan mitos-mitos lainnya (14). Mitos tersebut seringkali lebih dipercaya daripada kenyataan yang ada. Oleh karena itu, mitos seputar susu harus dihilangkan lewat praktik minum susu disertai riset tentang perilaku minum susu.

Pendidikan gizi pada mahasiswa dan dewasa diperlukan guna mencapai status gizi yang baik dan berperilaku gizi yang baik dan benar. Gizi seimbang bagi mahasiswa pun sangat diperlukan mengingat mereka membutuhkan vitamin dan mineral dalam jumlah cukup karena sangat berhubungan dengan proses pertumbuhan serta kondisi pubertas yang dialami saat ini (7). Seperti pada contoh menu gizi sembang bagi remaja, baik menu sarapan, makan siang atau makan malam, maka 1 gelas susu rendah lemak selalu muncul dalam menu sarapan, sementara untuk makan siang maupun makan malam menu minuman hanya berupa air putih. Berdasarkan contoh menu gizi seimbang bagi remaja tersebut di atas mengisyaratkan bahwa susu tetap dibutuhkan bagi remaja. Sementara susu itu sendiri hanya dimunculkan pada pagi hari yaitu pada menu sarapan. Penambahan susu pada gizi seimbang dimaksudkan untuk meningkatkan nilai gizi susunan hidangan, terutama karena kualitas protein yang rendah pada susunan hidangan Indonesia yang sebagian besar bersumber dari protein nabati. Namun, banyak masyarakat Indonesia yang enggan mengkonsumsi susu karena menderita lactose intolerence (yang berakibat diare) (1).

Sering kali muncul keengganan minum susu pada remaja dengan alasan susu dianggap akan menyebabkan kegemukan. Khususnya remaja putri, keinginan untuk kurus mengakibatkan keengganan untuk mengkonsumsi susu karena susu itu kaya lemak dan dipercaya akan mengakibatkan kegemukan. Tubuh langsing yang menjadi idaman remaja putri sering menjadi penyebab masalah gizi karena adanya pengaturan pembatasan makanan secara keliru yang dipraktikan oleh para remaja putri. Pemahaman gizi yang keliru ini akan mengakibatkan tidak terpenuhinya asupan gizi sesuai dengan kebutuhan (15). Padahal vitamin A, D, K, B2, niacin, B6, dan B12 yang terdapat dalam susu memiliki banyak fungsi yaitu untuk kesehatan mata, pembentukan membran mokus, pertumbuhan tulang, reproduksi, imunitas tubuh, dan antioksidan. 
Hal yang kontras dengan pandangan mahasiswa tentang gizi yang keliru adalah munculnya kesenangan terhadap kafe susu yang ada di DIY. Beberapa kafe susu yang tersebar di lingkungan kampus atau jalan-jalan utama Kota Yogyakarta maupun Sleman dipenuhi oleh pengunjung remaja. Kafe susu yang mulai membuka usaha pukul 09.00-21.00 setiap hari akan dipenuhi pengunjung remaja, sebaliknya pada akhir pekan (Sabtu dan Minggu) pengunjung keluarga terlihat cukup banyak disamping pengunjung remaja.

Penelitian terkait konsumsi susu pada remaja telah banyak dilakukan, tetapi yang khusus menyoroti konsumen mahasiswa di kafe susu masih jarang. Motivasi remaja SMP dan SMU di Bogor menunjukkan bahwa dalam mengkonsumsi susu dipengaruhi oleh faktor intern dan ekstern. Secara intern remaja termotivasi mengkonsumsi susu karena alasan kesehatan, makanan bergizi, dan pertumbuhan. Faktor intern adalah kebiasaan keluarga yang mendorong responden mengkonsumsi susu sedangkan pengaruh teman tidak terlihat nyata (16). Berdasarkan latar belakang tersebut, tujuan penelitian ini adalah untuk mengetahui makna dibalik konsumen mahasiswa di kafe susu, apakah ada makna intrinsik yang tersirat dan ekstrinsik yang tersurat dari kebiasaan mereka mengkonsumsi susu di kafe susu?

\section{BAHAN DAN METODE}

Penelitian kualitatif dengan metode pengumpulan data observasi dan wawancara dilakukan pada Juli dan Agustus 2014 dengan dibantu mahasiswa Departemen Antropologi, Fakultas Ilmu Budaya Universitas Gadjah Mada (UGM). Instrumen penelitian dikembangkan oleh peneliti, sementara mahasiswa sebagai asisten lapangan hanya bertindak melakukan observasi dan wawancara saja. Observasi naturalistik diterapkan yaitu observasi dilakukan di dunia nyata atau setting alami (17). Hal ini dimaksudkan untuk mengamati aktivitas mahasiswa dari masuk ke kafe susu, memilih pesanan susu, menunggu pesanan, menikmati susu, sampai mereka ke luar dari kafe susu. Sementara itu, wawancara informal secara tidak terstruktur dilakukan agar diperoleh makna dibalik aktivitas ke kafe susu baik mengenai tujuan utama ke kafe susu, aktivitas yang dilakukan selama berada di kafe susu, dengan siapa mereka ke kafe susu serta perbincangan apa yang dilakukan selama berada di kafe susu.

Observasi dan wawancara dilakukan terhadap 20 mahasiswa (10 pria, 10 perempuan) yang mengunjungi kafe susu baik yang rutin (seminggu sekali) maupun tidak rutin (sebulan sekali). Pengunjung difokuskan ke kafe susu yang terkenal dan ramai di seputaran kampuskampus seperti KL (initial), SL (initial), JS (initial), CC (initial), dan GM (initial). Wawancara dilakukan di kafe susu di Yogyakarta dan Sleman, maupun di kediaman para informan konsumen kafe susu. Pedoman wawancara sederhana dipakai untuk memandu wawancara agar fokus pada masalah gaya hidup konsumen mahasiswa di kafe susu tersebut.

\section{HASIL}

\section{Karakteristik informan}

Karakteristik pengunjung kafe susu didasarkan pada usia dan status pekerjaanya yaitu mahasiswa. Mahasiswa yang diwawancara terdiri dari 10 putri dan 10 putra yang berusia antara 18-23 tahun. Wawancara umumnya dilakukan di kafe susu pada saat mereka menikmati minuman tersebut, sementara itu sebagian kecil lainnya diwawancara di rumah kediaman atau tempat kos. Syarat untuk menjadi informan adalah pernah (1-2 kali) dan sering (1-4 kali setiap bulan) menikmati susu di kafe susu. Wawancara dilakukan dengan panduan daftar pertanyaan sesuai dengan topik yang diteliti. Para informan kebanyakan diwawancara di waktu malam hari saat mereka berkunjung ke kafe susu sedangkan yang diwawancara di rumah waktunya disesuaikan dengan aktivitas dan waktu luang responden.

Kafe susu yang dipakai untuk melakukan pengumpulan data penelitian ini pada umumnya berlokasi di Kabupaten Sleman, di lokasi yang berada tidak jauh dari beberapa kampus perguruan tinggi negeri maupun swasta. Lokasi kafe susu adalah di jalan-jalan utama menuju kampus dan untuk menjangkau kafe susu tersebut, mahasiswa berjalan kaki, naik motor atau kendaraan roda 4. Jam buka kafe susu diawali dari jam 09.00-21.00 tanpa ada hari libur, beberapa diantaranya buka pukul 10.0022.00. Pengunjung remaja atau mahasiswa mulai bersantai ke kafe susu pada jam-jam setelah selesai kuliah. Sore hari 
sampai malam hari merupakan jam-jam sibuk bagi pelayan kafe susu karena jumlah pengunjung akan penuh.

Interior kafe susu pada umumnya bergaya stylish dengan nuansa yang menarik, dengan kursi berbentuk bangku, kursi taman maupun kursi bulat yang agak tinggi. Ruangan yang lapang dan terdiri dari sekumpulan meja dan kursi dengan jumlah yang cukup banyak memungkinkan sekompok mahasiswa untuk datang bergerombol. Terdapat beberapa kursi dengan jumlah sampai lebih dari 10 dalam satu meja. Apabila bangku sebagai tempat duduk dirasa kurang maka kursi bulat kecil dapat ditarik untuk menambah pengunjung yang datang dalam satu kelompok/grup. Setiap meja yang tersedia, selalu tertera papan nama kecil bertuliskan nomor meja serta password jaringan internet. Password juga dipasang di dinding maupun dekat kasir. Wifi merupakan fasilitas yang ada di semua kafe susu sehingga internet gratis ini dapat dimanfaatkan pengunjung untuk berbagai keperluan. Sambil menikmati hidangan susu segar, pengunjung dapat memanfaatkan internet sepuasnya.

\section{Tujuan mengkonsumsi susu di kafe susu}

Susu segar yang sering dianggap amis, tetapi di tangan pengusaha kafe susu, susu diubah menjadi tidak amis sama sekali bahkan beraroma aneka rasa yang segar. Variasi rasa yang ditawarkan pun sangat beragam seperti cookies, almond, stroberi, mangga, leci, alpukat, jeruk, oat, kopi, greentea, vanila, atau hanya plain (susu putih tanpa rasa). Susu dengan rasa buah dikenal sebagai susu smoothies (buah dan susu diblander). Sementara susu segar yang ditawarkan kafe susu merupakan susu segar asli produsen lokal yang dimodifikasi dengan tambahan rasa maupun warna sehingga lebih disukai konsumen. Susu segar tanpa tambahan rasa dianggap membosankan dan akan terasa amisnya, sementara dengan penambahan rasa dan ditambah kekentalan yang sesuai maka susu menjadi minuman yang digemari kaum muda. Ukuran gelas yang ditawarkan akan mengikuti harganya. Dengan bentuk gelas yang unik sampai gelas ukuran jumbo yang berisi 400 cc susu segar ditawarkan oleh pengusaha kafe susu. Takaran yang besar ini cukup digemari pelanggan sebab dengan minum 1 gelas saja akan terasa kenyang.

Tujuan mengkonsumsi susu di kafe susu disadari sepenuhnya oleh semua informan. Selain manfaat kesehatan yang akan diperoleh, mereka juga paham akan kandungan mineral dan vitamin pada susu. Bahkan, manfaat minum susu telah informan ketahui sejak SD seperti penuturan informan Z: "Sejak SD saya sudah diberi pelajaran tentang pentingnya minum susu karena kandungan vitamin dan mineralnya baik untuk tubuh"

Perubahan dalam hal kesehatan dirasakan oleh para penikmat kafe susu serta mereka yang membiasakan minum susu di rumah maupun di kafe susu. Tubuh yang semakin bugar dan jarang sakit serta tidak mudah lelah menjadi pertimbangan untuk selalu mengkonsumsi susu di kafe susu. Bahkan, seakan-akan jika belum minum susu baik dari kafe susu maupun membeli susu kemasan pabrik terasa ada yang kurang. Susu bagi responden menyehatkan badan, seperti dituturkan informan B (19 tahun) berikut ini: "Selama saya minum susu, saya jarang sakit. Ngerasa fit terus badan ini”. Minum susu seperti sebuah doping yang dipakai mahasiswa untuk mendukung aktivitasnya yang beragam. Terlebih mahasiswa yang memiliki pekerjaan paruh waktu dan tidak sempat sarapan maupun makan kenyang, merasa bahwa minum susu mampu menjaga stamina responden dari jadwal keseharian yang padat.

Saat pesanan dihidangkan ke meja, akan terlihat beragam rasa dan warna sesuai dengan pemesannya, ada pula yang diatasnya ditaburi beragam topping. Jika pelanggan datang berombongan misalnya 6-12 orang dengan pemesanan beraneka rasa maka jajaran gelasgelas yang ada akan sangat menarik perhatian karena masing-masing berbeda rasa, warna, dan ukuran. Suasana ramai ditambah jajaran gelas yang menarik sebelum susu diminum inilah yang menjadi background saat mereka foto selfie. Selfie lebih sering ditemukan pada pengunjung kelompok perempuan. Momen ulang tahun, ditraktir teman atau hang out bersama kelompok paling menarik untuk diunggah di media sosial. Sementara itu, di kafe susu lainnya terlihat 4 kelompok diskusi yang masingmasing beranggota 2-4 mahasiswa yang memegang laptop. Mereka tekun memandangi data-data di laptop mereka yang terhubung dengan internet gratis dari kafe tersebut. Terlihat gelas susu mereka telah habis, tetapi mereka belum beranjak pergi.

Selain menfoto suasana dan hidangan, pengunjung remaja berusaha membuat memori yang indah dengan 
lokasi yang berbeda dari biasanya. Umumnya, dari foto yang di upload di media sosial tersebut kemudian mendorong teman lain untuk mencoba ke kafe susu tersebut untuk mencicipi sensasi susu seperti yang dibicarakan teman mereka. Ada pula mereka yang sebelumnya kurang suka minum susu menjadi tertarik mencobanya karena cerita dari teman-teman sebayanya yang telah terbiasa ke kafe susu. Informan yang berinisial $\mathrm{R}$ menceriterakan pengalamannya:

"Wah aku seneng banget ada tempat kayak kafe KM (initial), udah tiga tahun aku langganan ke sana. Suasananya tenang sambil nongkrong sama teman-teman dan ngobrol bareng. Tempatnya asyik, buat foto-foto bareng teman-teman juga seru....".

Kafe memiliki arti yaitu minuman sehingga pergi ke kafe dapat menjadi trend setter di kalangan mayarakat khususnya kaum muda. Nongkrong di kafe susu dirasakan sebagai kenikmatan yang berlipat ganda. Fasilitas tempat yang nyaman dan eksklusif karena tidak setiap orang mampu membeli harga minuman di kafe susu, suasana yang harmoni, ada alunan musik, cita rasa minuman yang nikmat, enak, serta nyaman untuk bersenda gurau dengan teman, sahabat, teman kampus merupakan suasana khas kafe susu. Pengunjung dapat duduk di sofa berlama-lama tanpa takut ditegur pemilik. Pelayanan yang ramah menambah daya tarik tersendiri bagi para pengunjung. Konsep kafe susu yang modern dan minimalis menjadikan suasana kafe susu cocok untuk nongkrong yang mengasyikkan dan gaul. Penikmat kafe susu informan F (mahasiswi program S2) menyebutkan:

"Kafe susu merupakan tempat tongkrongan yang sehat sekaligus gaul serta dapat dijadikan lokasi berkumpul bersama teman-teman"

Rasa enak yang ditawarkan oleh kafe susu membuat pengunjung ketagihan. Minum susu di kafe susu menjadi suatu kebiasaan yang akan diulang-ulang (addicted). Hal ini karena image susu yang melekat dengan bau amis akan sirna setelah mencicipi susu dari kafe susu. Aroma yang muncul justru aroma segar yang mengundang selera. Bau amis tidak terlihat lagi, bahkan yang ada adalah susu segar yang menggugah selera baik karena rasanya maupun tampilannya. Sajian dingin paling disukai oleh konsumen kafe susu.

\section{Demi gengsi}

Di kalangan penggemar susu di kafe susu KM terdapat istilah neneners. Istilah tersebut dipakai oleh pelayan kafe susu untuk menyebut konsumen dan penggemar berat minuman susu yang datang di kafe susu itu. Neneners menjadi julukan yang unik bagi pelanggan guna berkomunikasi diantara sesama neneners maupun pelanggan dan pelayan. Akibatnya, neneners merupakan kelompok yang ekslusif karena tidak setiap orang dapat menjadi bagian dari penggemar susu tersebut. Ada gengsi yang melekat dengan sebutan neneners tersebut.

Berkunjung ke kafe susu telah menjadi kebiasaan banyak mahasiswa untuk mengisi waktu kosongnya. Mereka datang ke kafe susu dengan beragam tujuan. Salah satu pengunjung informan IA (mahasiswa, 20 tahun) menyatakan:

"Saya tidak minum susu di kafe susu demi kesehatan, saya tetap minum susu di tempat kos sehari 2 kali, meskipun hari itu sudah ke kafe susu. Bagi saya kalau ke kafe susu itu nongkrongnya dapet sehatnya juga dapet. Sehat itu murah tapi sakit itu yang mahal"

Rata-rata para pengunjung kafe susu umumnya penduduk Yogyakarta maupun para pendatang. Para pengunjung yang didominasi mahasiswa tersebut telah memiliki kebiasaan minum susu sejak kecil. Namun, setelah mereka belajar ke Yogyakarta dan berpisah dengan keluarga mengakibatkan hilang pula kebiasaan minum susu. Ada sebuah kasus yang dialami informan $\mathrm{CH}$ yang mencoba memasak susu segar di tempat kos, tetapi justru diprotes teman kos akibat bau amis yang ditimbulkannya. Setelah peristiwa tersebut, informan mengaku lebih menyukai ke kafe susu apabila menginginkan susu segar yang telah ia kenal sejak kanak-kanak.

Gaya hidup minum susu di kafe susu selain diperoleh lewat iklan dari twitter, facebook, dan televisi lokal yang menyajikan acara kuliner, juga diperoleh dari informasi dan rekomendari teman-teman yang telah mencoba ke kafe susu. Rasa nyaman dengan suasana 
kafe susu ditambah rasa susu yang enak menjadikan para pengunjung merasa puas. Akibatnya, mereka akan kembali lagi untuk menikmati susu dengan rasa favorit mereka.

Dibandingkan susu segar yang dijual di kaki lima dengan label susu asli Boyolali, memang kafe susu jauh berbeda. Susu segar di kali lima rasanya kurang variatif dan disajikan dalam kondisi panas. Sementara di kafe susu, terdapat pilihan susu segar dingin, dan inilah yang paling banyak disukai pengunjung. Namun, di kafe susu pengunjung juga dapat memilih susu panas, harga susu bukan ditentukan panas atau dingin dalam penyajiannya melainkan dari rasanya.

Demi mengikuti gaya hidup nongkrong di kafe susu, tidak sedikit mahasiswa yang merasa boros dalam pengeluaran. Harga segelas susu di kafe susu tidaklah murah bagi kantong mahasiswa, dengan kisaran Rp 15.000-25.000 per gelas. Mereka pada umumnya tidak hanya memesan segelas susu melainkan dengan camilan lain yang disediakan kafe susu dengan harga yang tidak murah pula. Akibat sering ke kafe susu, informan $\mathrm{F}$ (mahasiswa S2) mengaku pengeluarannya meningkat. Ia awalnya cukup menghabiskan Rp 1.200.000 per bulan untuk makan dan minum. Namun, setelah ia rajin mengunjungi kafe susu ia meminta kiriman uang dari orang tua sebesar Rp 2.000.000 per bulan dengan alasan harga makanan dan minuman telah naik. Kebiasaan mengkonsumsi susu di kafe susu mampu membuat seseorang terpaksa mencari alasan yang rasional agar orang tuanya mengabulkan permintaan tambahan kiriman uang bagi anaknya.

\section{BAHASAN}

Kafe susu telah menciptakan ruang baru bagi mahasiswa untuk mewadahi segala aktivitas mereka. Mereka memanfaatkan ruang di kafe susu untuk mengerjakan tugas kuliah melalui searching bahan dari internet, diskusi kelompok, reuni, mengobrol atau sekedar selfie kemudian mengunggahnya di media sosial. Ruang kafe susu yang dikemas apik, lapang, ber-AC atau sirkulasi udara nyaman, kursi/bangku yang banyak, ditambah interior dan pewarnaan ruang yang cozy menambah kenyamanan pengunjung. Namun, satu hal yang paling dimanfaatkan dengan baik adalah tersedianya wifi yang gratis sehingga pengunjung dapat bermain internet tanpa membayar lagi meski duduk berjam-jam.

Keleluasaan kafe susu antara lain dibukanya ruang sampai malam. Beberapa kafe susu tutup sampai pukul 22.00. Setelah aktivitas di kampus telah selesai, ditambah perpustakaan kampus pun telah tutup, mahasiswa dapat menggunakan kafe susu untuk aktivitas lanjutan melalui pengerjaan tugas di ruang tersebut. Letak kafe susu yang strategis, di pinggir jalan utama menuju kampus memudahkan mahasiswa untuk menjangkaunya. Selain itu, dalam arena kultural terdapat arena-arena yang paling sering diasosiasikan dengan kebudayaan seperti gaya pakaian, penataan rumah, preferensi dalam film, lukisan, musik, olahraga, dan sebagainya. Namun, ada pula arena kultural yang lebih abstrak seperti disposisi etis, moral, preferensi politik, humor, kepekaan psikologis termasuk karakteristik manusia yang paling alami yaitu selera makanan (18). Selera makanan dan minuman ini kemudian menjadi tolok ukur kelas sosial masyarakat penggunanya.

Susu dari makna ekstrinsik (natural signs) adalah sebuah cairan warna putih pekat yang dihasilkan dari sapi, kambing, kuda, onta yang mengandung nilai gizi yang tinggi. Nilai benda ini merupakan tanda-tanda alamiah serta menimbulkan reaksi yang sama pada setiap orang. Sementara itu, makna intrinsik (tersirat, tersembunyi atau significant symbols) dari susu di kafe susu yaitu berupa simbol-simbol yang mengandung makna tetapi tidak harus menimbulkan reaksi yang sama bagi setiap orang (19). Berdasarkan penuturan para informan, terbukti bahwa makna tersembunyi lebih kuat daripada yang tersurat. Simbol gengsi, modern, gaul serta tempat hang out lebih dominan daripada nilai gizi susu itu sendiri.

Susu yang dahulu dikonsumsi karena propaganda pemerintah terkait konsep 4 sehat 5 sempurna yang kemudian berubah menjadi konsep gizi seimbang sekarang telah mengalami transformasi bukan sekedar memenuhi aspek kesehatan melainkan aspek lainnya termasuk gaya hidup. Konsumsi susu bukan lagi ke bendanya, tetapi ke simbol-simbol yang melekat pada benda tersebut. Manipulasi juga melekat pada konsumsi. Kegiatan konsumsi menciptakan nilai simbolik baru 
yang sebenarnya merupakan manipulasi. Disebutkan bahwa hiper-realitas yaitu sebuah benda dinilai melebihi realitasnya sehingga orang tidak dapat lagi membedakan yang nyata dengan yang fiksi (20).

Transformasi susu justru dikreasikan oleh pengusaha kafe susu lewat pengubahan rasa susu dan cara penyajiannya sehingga susu akan diproduksi dengan cara baru. Dengan demikian, dapat menghasilkan uang dan menciptakan identitas baru. Mereka yang sering mengunjungi kafe susu akan dianggap sebagai anak gaul, serta kafe susu menjadi tempat tongkrongan yang bergengsi. Nongkrong di kafe susu menjadi hal yang positif sebab kafe susu identik dengan sesuatu yang sehat.

Minuman susu di kafe susu telah mengubah fungsi susu itu sendiri. Fungsi susu yang semula sebagai minuman kesehatan berubah fungsi menjadi gaya hidup modern dan masyarakat kota. Tempat minum susu yang dahulu adalah di warung susu pinggir jalan setelah berubah tempat menjadi di kafe yang menjadi simbol kehidupan kota. Susu segar yang biasanya dikonsumsi tanpa tambahan aroma kecuali kopi, coklat, atau putih (plain) tanpa rasa, oleh pengusaha kreatif kemudian diubah tampilannya baik dari segi rasa, aroma, maupun cara menikmatinya. Tempat, lokasi, serta ornamen kafe susu yang nyaman serta ruang ber-AC, parkir luas, dekorasi, dan tempat duduk yang indah ditambah fasilitas wifi telah menyempurnakan kebutuhan kaum muda untuk rileks, bersantai sekaligus bergaul sambil mengerjakan tugas kampus melalui layanan wifi gratis. Rasionalitas pengunjung cafe remaja muncul sebab sekali datang ke kafe susu maka dua-tiga tujuan akan tercapai.

Tidak ada kesan negatif pada kafe susu. Sebaliknya, kafe lain seperti kafe yang buka hanya saat malam sampai dini hari (kafe khusus hiburan malam) sering identik dengan alkohol, minuman keras, rokok bahkan peredaran narkoba. Sementara kafe susu justru sebaliknya, sebab tempat tersebut identik dengan menjual kesehatan dan gengsi.

You are what you eat. Apa yang dikonsumsi oleh seseorang merupakan cerminan siapa dirinya. Dalam konsumsi susu di kafe susu, para konsumen mengaku ada rasa kepuasaan serta rasa bahagia dan tentram setelah mengkonsumsinya. Hal itu menunjukkan bahwa makanan atau minuman terkandung manfaat dari aspek psikologis. Aspek lain yaitu aspek sosial, yaitu minum susu apalagi di kafe susu yang harganya tidak murah, ada anggapan hanya kelompok ekonomi menengah atas sajalah yang mampu melakukannya. Ditambah lagi secara luas di masyarakat, masih kuat adanya anggapan hanya orang kota (kaya) sajalah yang mampu minum susu. Bagi orang kebanyakan, susu masih dipercaya sebagai minuman yang berharga mahal meski manfaat bagi kesehatan juga segudang. Adanya added value dari mengkonsumsi susu di kafe susu yaitu sehatnya dapat dan gengsinya juga dapat sehingga mengakibatkan perilaku minum susu di kafe susu tidak akan surut dari kehidupan remaja khususnya mahasiswa. Terpenuhinya kebutuhan konsumen akan nilai susu menimbulkan suatu rasa kepuasaan bagi konsumen. Susu juga memberikan manfaat (utility). Harga, waktu, dan tenaga yang harus dibayar konsumen untuk menikmati segelas susu dari kafe susu sebanding dengan manfaatnya (21).

Frame of reference kesadaran dari mereka bahwa mengkonsumsi susu di kafe susu akan menguatkan identitas seseorang dalam bergaul, berkomunikasi, dan bersosialisasi mengakibatkan harga bukanlah menjadi pertimbangan yang mereka pikirkan, asalkan aktivitas minum susu di kafe susu bermanfaat bagi diri (kesehatan) dan lingkungannya (pergaulan). Pertimbangan lain bahwa manfaat yang diperoleh setelah konsumsi susu di kafe susu adalah sebanding dengan pengeluarannya, baik menyangkut waktu, uang atau biaya, dan perasaan gembira sehingga kebiasaan ke kafe susu akan terus diulang-ulang. Kegembiraan dari minuman yang dikonsumsi akan mengaktifkan produksi hormon kebahagiaan (22).

Susu adalah produk peradaban modern, yang muncul setelah manusia mengenal sistem peternakan dan pengolahan hasil ternak. Pada diet zaman batu yang sekarang ini mulai diadaposi masyarakat barat, produk susu, kacang-kacangan, biji-bijian, serelia yaitu makanan yang dikenalkan setelah penemuan metode memasak dan bercocok tanam, harus dihindari (23). Sebaliknya, dalam menu masyarakat modern justru susu menjadi minuman yang wajib ada dalam kehidupan manusia sehari-hari. Ini menegaskan bahwa susu merupakan produk peradaban modern.

Kembali ke manfaat sehatnya dapat dan gayanya juga dapat akan semakin terpatri kuat di benak kawula 
muda sebagai kelompok yang selalu mengedepankan identitas kelompoknya selain identitasnya sendiri. Sebutan neneners bagi penyuka susu pun turut memperkuat identitas mereka. Bagi kawula muda, simbol-simbol yang memperkuat identitas mereka cenderung selalu dicari, meski harus ada pengorbanan yang mereka keluarkan.

\section{SIMPULAN DAN SARAN}

Keberadaan kafe susu di Yogyakarta telah mampu mengubah makna dan tujuan orang mengkonsumsi susu. Awalnya susu sebagai minuman kesehatan, kebugaran, dan pendongkrak stamina tubuh berubah ke gaya hidup mahasiswa sebagai tempat santai, hang out, sharing, berkumpul, dan yang penting yaitu mengerjakan tugas dari kampus. Rasionalitas pengujung mahasiswa ke kafe susu muncul karena nilai intrinsik lebih kuat daripada ekstrinsik, selain gaul dan gengsi, mereka juga memperoleh manfaat kesehatan dan ekonomi yaitu tubuh semakin bugar dan tidak perlu lagi membayar biaya penggunaan wifi selama berkunjung ke kafe susu. Sementara itu, manfaat gizi menyertai manfaat simbolnya.

Keberadaan kafe susu dengan konsumen utama mahasiswa perlu ditingkatkan jumlahnya disertai pemahaman nilai gizi yang terkandung di dalam susu. Pemilik kafe susu perlu kerjasama dengan instansi terkait seperti Dinas Kesehatan, melalui pembuatan iklan atau media lain agar sosialisasi hidup sehat lewat minum susu dari sisi pendidikan menjadi lengkap.

\section{Pernyataan konflik kepentingan}

Penulis menyatakan tidak ada konflik kepentingan dengan pihak-pihak yang terkait dalam penelitian ini.

\section{RUJUKAN}

1. Campbell TC, Campbell TM. Rahasia sehat orang China. Jakarta: Noura Books; 2013

2. Sediaoetama AD. Ilmu gizi II. Jakarta: Dian Rakyat; 2004.

3. Syarifah F. Di Asia tenggara konsumsi susu di Indonesia paling rendah. [series online] 2013 [cited 21 Juni 2014]. Available from: URL: http:/health.liputan6. com/read/695895/di-asia-tenggara-konsumsi-susu-diindonesia-paling-rendah

4. Counihan, C.M. The anthropology of food and body. London: Routledge; 1999.

5. Purwaningrum DN, Hadi H, Gunawan IMA. Faktor risiko obesitas pada ibu rumah tangga miskin. Jurnal Gizi Klinik Indonesia 2012;9(1):1-9.

6. Hardiansyah E, Damayanthi W, Zulianti. Hubungan konsumsi susu dan kalsium dengan densitas tulang dan tinggi badan remaja. Jurnal Gizi dan Pangan 2008;3(1):4348.

7. Devi N. Nutrition and food: gizi untuk keluarga. Jakarta: PT Kompas Media Nusantara; 2010.

8. Liestyasari SI. Kaum muda dan konsumsi identitas Yogya. Yogyakarta: Penerbit Kanisius; 2005.

9. Pearce EC. Anatomi dan fisiologi untuk paramedis. Jakarta: Gramedia Pustaka Utama: 2013.

10. Umami Z, Nurdiana, Nugroho FA. Efek pemberian susu sapi bubuk terhadap kadar serum HDL (high density lipoprotein) pada tikus putih (Rattus norvegicus) Galur Wistar model diabeters melitus tipe 2. Jurnal Gizi dan Pangan 2015;10(1):1-8.

11. Hadi AD. Ensiklopedi binatang penyembuh. Yogyakarta: Citra Media; 2011.

12. Hasibuan MS, Aritonang EY, Nasution E. Gambaran perilaku konsumsi susu pada siswa Ar-Rahman Medan tahun 2012. Jurnal FKM USU 2012;4(2):15-21.

13. Roth RA. Nutrition and diet therapy. New York: Delmar; 2013.

14. Winarno FG. Susu dan kesehatan manusia. Jakarta: Gramedia Pustaka Utama; 2016.

15. Marni. Gizi Dalam Kesehatan Reproduksi. Yogyakarta: Pustaka Pelajar; 2013.

16. Komarudin C. Faktor-faktor yang mempengaruhi konsumsi susu pada remaja [Skripsi]. Bogor: IPB; 2000.

17. Tashakkori A, Teddlie C. Handbook of mixed methods in social and behavioral research (Alih Bahasa: Daryatno). Yogyakarta: Pustaka Pelajar; 2010.

18. Lee MJ. Kebudayaan konsumsi dan komoditas. Bantul: Kreasi Wacana;2015.

19. Ritzer G. Sosiologi ilmu pengetahuan berparadigma ganda. Jakarta: Rajawali Pers; 1999.

20. Eco U. Travels in hyperreality. Boston: Houghton Miffin Harcourt; 2014.

21. Aritonang I. Krisis ekonomi akar masalah gizi. Yogyakarta: Media Pressindo; 2000.

22. Haruyama S. The miracle of endorphin. Bandung: Mizan Pustaka; 2013.

23. Gibbons A. Evolusi diet. National Geographic 2014; September: 42-67. 